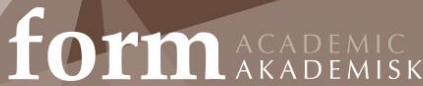

https://doi.org/10.7577/formakademisk.4204

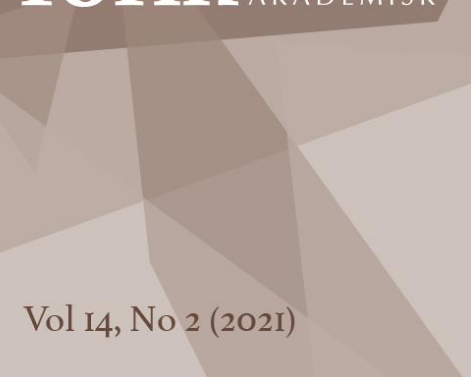

Trine Møller

PhD

Independent researcher moellertrine@live.dk

Kirstine Riis Associate Professor

University of South-Eastern Norway kriis@usn.no

\title{
Exploring craft practice in learning communities
}

\begin{abstract}
This paper presents an initial research project to explore what characterizes knowledge production in craft practice situated in an informal/neutral learning arena outside the education institution. The research project is carried out by craft and design researchers from Norway and Denmark. The project participants include students, academics, older generation volunteers with craft experience, freelance designers, and arts and craft persons, as well as researchers. The overall methodology is a case study approach and has references to practice-led research, participatory design research and $A / R /$ Tography. In this paper we present the research design of the project. Along a theoretical framework consisting of research perspectives of each of our institutional traditions, we lastly discuss the challenges in engaging a neutral learning arena, throughout and as preparation for our research project.
\end{abstract}

Keywords:

craft practice, learning communities, neutral learning arena, craft research

\section{INTRODUCTION}

In Denmark and Norway, craft practice and creative learning are today exercised in different learning arenas. First, at formal educational institutions at different levels. Secondly, in informal social learning arenas, such as arts and craft communities, classes, afternoon clubs, etc., or informal individual learning arenas such as online learning courses and materials e.g. video and blogs on the Internet.

The learning arenas at the formal institutions are characterized by, and limited to, bureaucratic terms with requirements of documentation and control systems i.e. study plans with learning goals and competency measurements of the student's work. On the other hand, informal learning arenas are characterized by more flexibility and the ability to reconfigure the learning situation in-situ. Especially, taking into account the participant's interests, expectations, and personal competencies.

This paper outlines a research project to facilitate and explore the potential of knowledge production in craft practice situated between formal and informal learning arenas at a neutral learning arena, see figure 1. 


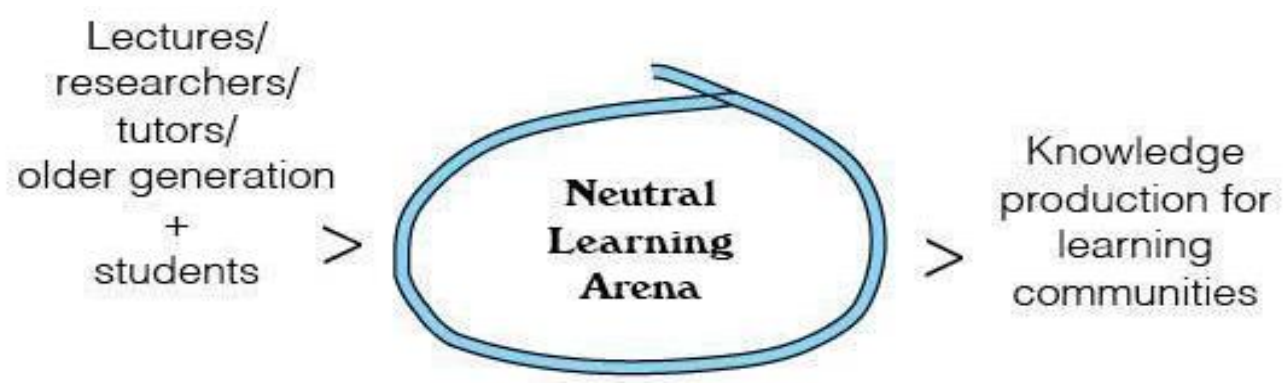

FIGURE 1: The knowledge flow of the research project.

The overall aim of the project is to facilitate learning communities for preserving and developing traditional craft practice with focus on sustainable craft-based production and learning. We assume that key answers for a sustainable future are found in our craft heritage and that future consumption is closely related to craft-based sustainable production and learning. We also believe that sustainable craft production and learning is important for sustainable living in a broader sense, e.g aspects as health (Kirketerp, 2020) and democracy (FNs sustainable development goals, United Nations, 2020).

We hypothesize that in informal and neutral learning arenas outside the education institution, there are opportunities to facilitate knowledge production in the interactions/interplay between representatives from both formal and informal learning arenas such as teachers/researchers, freelance designers and artists, older generation crafts persons and students. A meeting place that facilitates the exchange of knowledge, professionalism and competencies within sustainable craft-based learning and production can potentially create dynamism and synergies between participants with different backgrounds and competencies and from different backgrounds and generations. These are synergies we believe contribute to both the preservation, development and innovation of traditional crafts, which in turn contribute to sustainable development, as well as increased public health and community participation for both the younger and older generation. In this research project, we facilitate, explore and evaluate the impact of these interactions.

The research question is: What characterizes knowledge production in craft practice taking place in a neutral learning arena in interactions between participants from both formal and informal learning arenas?

\section{RESEARCH DESIGN AND METHODOLOGY}

\section{Methodology, researcher roles and participants}

In this section, we present the research design and methodology of the project. The overall methodology of the study is qualitative case study methodology (Yin, 2009) and characterized by dynamic interplay between researchers from different research contexts, different but relevant theories and methodological references, craft traditions and related participants.

The two researchers in the project, Møller and Riis, have backgrounds and PhD degrees from different institutional contexts i.e Denmark (Design School Kolding) and Norway (University of SouthEstern Norway, USN/The Norwegian University of Science and Technology, NTNU). The project aims to give insight to knowledge production in craft practice in general, but each of the researchers own practices is rooted in textiles and the research is thus conducted within textile craft. The dynamic interplay between contexts and theories but also between concrete, sensuous experiences and conceptual, theoretical aspects characterizes the overall methodological approach of the project. Thus, 
the use of textile metaphors is used as a methodological strategy to link textile craft practice and research.

As researchers we will have the roles as both practitioners/textile craft makers, teachers and researchers and the project has methodological references to both practice-led research (Candy \& Edmund, 2018) and A/R/Tography (Irwin, Springgay \& Kind, 2005) rooted in arts-based research (Barone \& Eisner, 2011). Thus, the complexity of handling these different roles is rather seen as a premise for knowledge production than a difficulty. According to Irwin, Springgay \& Kind (2005), the three different roles hold opportunities and potentials for the researchers to be playful, explorative in the intersection between knowing and being - to generate expressive and innovative knowledge about craft practice ( $p$. 897-900).

\section{Cases; CRAFT/MAKING/MEETING at a neutral learning arena}

We create and implement the cases for exploration as events called CRAFT/MAKING/MEETING (CMM) at a neutral learning arena outside the educational institution. In the three cases, we facilitate, participate, document and analyze craft activities between selected participants gathered in so-called learning communities. Participants will be both students, academics, older generation volunteers with craft experience, freelance designers and arts and craft persons, as well as we as craft practitioners and researchers.

\section{Research design}

The research design is characterized by 4 phases, 1 theoretical and 3 empirically focused, figure 2 .

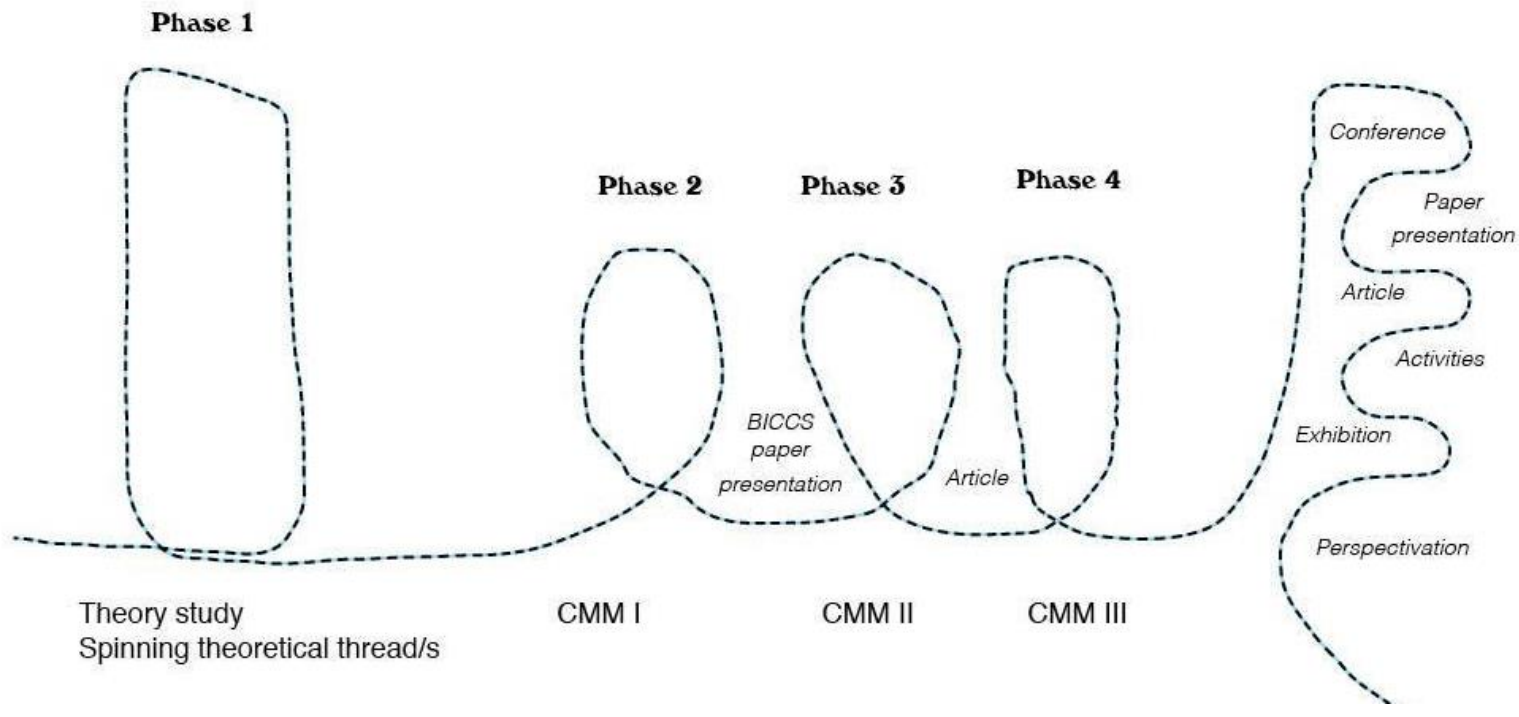

FIGURE 2: Model of research design.

The first phase of the project is a literature study aiming to explore and define the theoretical framework of the project. This includes the interaction between the two researchers and their different backgrounds and institutional contexts from Denmark (Design school Kolding) and Norway (University of South-Estern Norway). The different research traditions are documented in each of our PhD-projects. Reflecting on this, Møller (2019a) explored how a programmatic research approach (Brandt and Binder, 2007) could develop personal wearable health design for individuals with specific needs.

Møller carried out participatory design research (Binder and Brandt, 2008), as design experiments with students, wearable health companies, and in collaboration with different state-ofthe-art researchers and designers (Møller \& Kettley, 2017; Møller 2018; Møller 2019b). Riis (2016) explored design knowledge through her own creative work in a textile design process. Her methodological approach was practice-led (Riis \& Groth, 2020) at theoretical basis in practice epistemology 
specifically the theory of knowledge by the Swedish philosopher Bengt Molander The practice of knowing and knowing in practices (Molander, 2015).

We share, discuss and challenge different experiences and learning journeys within the craft and creative practice, rooted in both the college profession, design education, and academia over the past $20+$ years and intend to spin a theoretical thread useful for the research. We elaborate on this in the following section Theoretical framework. The research design furthermore explores 3 cases; CCM $1, \mathrm{CCM} 2, \mathrm{CCM} 3$ where learning in the CCMs is explored and evaluated. We plan to conduct three CMMs with different perspectives on textile craft activities from spring 2021 to fall 2021.

- $\quad$ CCM I explores how traditional and experimental textile craft techniques and methods interact between the participants and what characterizes the learning community in these interactions. Main focus: the relationships between the skilled apprentices and learners: students/teachers and how the learners learn from the older generation and/or masters of certain crafts.

CCM II explores the interaction between established and traditional textile craft techniques and methods and explorative/experimental and innovative processes. Main focus: mutual learning processes and possible effects in the perspective of sustainable textile craft production and learning.

- $\quad$ CCM III explore how site specific textile art projects can communicate the concept and concrete examples from the project on learning communities characterized by interactions between traditional textile craft techniques and methods and explorative/experimental and innovative processes, between different makers and learners, generations, traditions, and the relationship between formal and informal learning arenas/inside and outside institutions.

Methods used are participatory observation (Bloomberg et al. 1993), autoethnographic documentation of practice and related reflections (Ellis \& Bocher, 2000) and focus group interviews (Kvale \& Brinkmann, 2015).

We adopt an experimental approach with references to Binder and Brandt (2008). Thus, the CMMs can be seen as experimental activities happening in a 'design laboratory'. The CMMs therefore happen as 'process loops' where experiments and insights simultaneously influence each other (Krogh, Markussen and Bang, 2015). We understand these process loops as results of gradual shifts in the research focus, requiring continuous adjustments and openness for 'what to come' throughout the CMMs. We acknowledge that this form or dynamic of the CMMs can describe activities of a neutral learning arena, to inform the characteristics of knowledge production of craft practice in learning communities.

In line with this, empirical data will be analyzed in an abductive manner and knowledge generated through dynamics between empirical data and relevant theoretical perspectives and inductive and deductive reasoning (Alvesson \& Sköldberg, 2017). According to Professor of psychology and qualitative methods, Svend Brinkmann, an abductive dynamic furthermore presents the researcher with valuable moments of incidents of 'astonishment', 'mystery' or 'breakdowns' in understanding (2014). Brinkmann refers to this as 'stumbling experiences' that offer an opportunity to learn something new. This approach outlines a method for analyzing the empirical data to be used further in the third $\mathrm{CMM}$, as well as reflecting on the different levels in the project of both craft practice and craft research. According to Professor of design, Kristina Niedderer (2013) abduction, as a mode of productive reasoning, is an appropriate analytical strategy in creative practices and craft research because it is a creative and conjectural process (p. 21).

\section{THEORETICAL FRAMEWORK}

The research project facilitates our shared interests in different research traditions and perspectives of each of our institutions. In this section, we draw up contours of relevant perspectives based on the two 
authors' different research contexts from design, arts and craft research in Norway and Denmark and the institutions Design School Kolding, Denmark and the University of South-Eastern Norway. Figure 3 describes an overview of each of our institutional traditions. To justify our research ambition, we explore these proclamations from the time when we carried out our phD-studies.

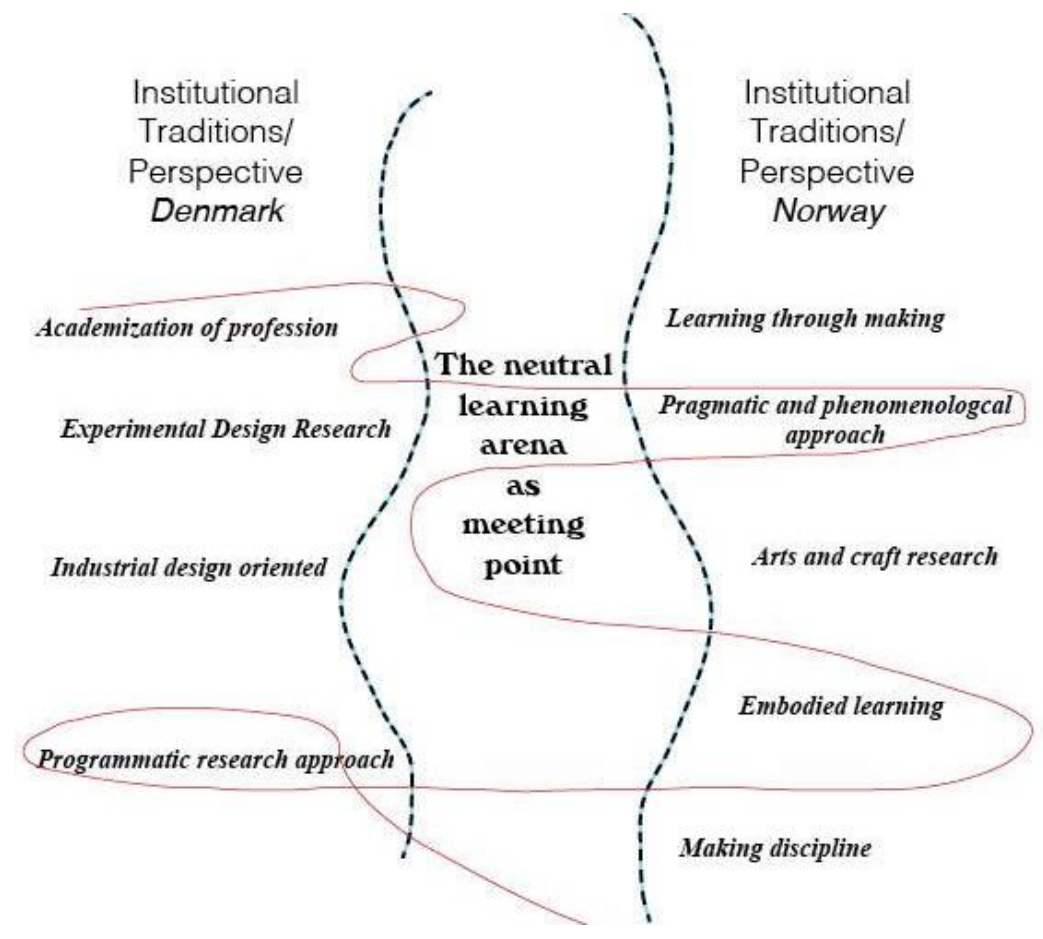

FIGURE 3: Theoretical framework inspiration.

We explore how each of our institutional traditions frame new synergies to be beneficial and fruitful to the research of craft practice and knowledge production for future craft learning communities. We aim to find and 'spin' together relevant theories for the project and draw up relevant theoretical lines structured respectively to discuss our approach exploring craft practice in learning communities outside the educational institution.

\section{Institutional perspective from Denmark and Norway, Design School Kolding and University of Southeastern-Norway}

Exploring the institutional perspectives and traditions in design research education in Denmark and Norway, we report mainly from the influence of the two researchers' contexts at Design School Kolding and University of South-Eastern Norway (USN).

Design School Kolding was accredited as a research institution in 2010 (Designskolen 2018). The institution was originally founded in 1967 as an Arts \& Craft school, but changed its name in 1998 to 'Design School Kolding (http://koldingwiki.dk/index.php?title=Designskolen). In 2003, Design School Kolding signed a consolidation Act to offer design education at BA and MA level under the Danish Ministry of Culture (www.designskolenkolding.dk). Since 2010 Design School Kolding has also offered academic education at PhD-level.

University of South-Eastern Norway, USN, was established as a university in 2018, when Telemark University College merged with Buskerud and Vestfold University college. USN, campus Notodden has a long tradition in teacher education and education within arts and craft from back 1938, and have since 1976 offered studies on graduate level, today named Master in design, arts and craft. From 2011 USN has offered academic education in craft at PhD-level (elaborated in the text below). The PhD-program in Culture studies at USN was accredited in 2011, having four main areas of the program: Cultural understanding, cultural policy, cultural production and aesthetic practice and cultural 
education. This enabled PhD-researchers with backgrounds from both traditional academia and from the field of creative and educational practice.

In the following section we first explore the history of academization of the design profession in these contexts, before we refer to research conducted in the field and draw lines to leading concepts and methods in the two contexts.

\section{Academization of the field of design and design didactics}

According to design historian Nigan Bayazit, it was design researcher and Professor at the Royal College of Art in London Bruce L. Archer, that in the early 1980s pioneered research in design and 'helped' to establish it as an academic discipline (2004). This statement is followed by Design historian Beat Schneider who claims that it was during the 1980s that design was defined and recognised as a science (2007). Bayazit writes about these spiring aspirations to be rooted in the 'De Stijl' movement in the early 1920 s as part of the Bauhaus movement. 'The roots of design research in many disciplines were found within the Bauhaus tradition that was established as the methodological foundation of design education.' (2004, p. 17).

The Bauhaus model also inspired the educational structure at Design School Kolding, as well as it's research traditions. Both the Danish and the Norwegian context referred to in this text is inspired by the work of Archer (1995) and Frayling (1993). Frayling coined the term 'Research through Design' (Ibid.) to employ methods and processes from design practice into research. In relation to design research the term Research through Design is understood as a research approach that recognizes the process of making and designing as a legitimate method of inquiry for design research. Encouraged by Archer and Frayling different concepts emerged from the different contexts in the field, i.e. art based research, artistic research, practice-based research, practice-led research, research through design, research by design, making professions, systemic design with similar, overlapping or diverse methodologies related.

According to Thomas Markussen, Anne Louise Bang, Eva Knutz and Pia Pedersen, who also were among the first PhD-students at Design School Kolding, Research through Design aims to establish a research approach that fulfills an intellectual culture of its own (2012). Their research is highly influenced by 'Anglo-Scandinavian' scholars and perspectives on design research. Other Danish scholars also wrote about theoretical frameworks for design research. Especially Eva Brandt and Thomas Binder, who now both are Professors at Design School Kolding. In their research contribution on experimental design research in 2007, they present a framework based upon the idea that design experiments play a key role as a vehicle for knowledge production. They suggest that a Research through Design approach in a project can be defined in terms of a research question, program and experiment, and thereby coin the act of 'programming experiments in design research' (Ibid., p. 2).

In Norway, there has been a long discussion about how research through artistic or designery practice should and could be conducted in the creative fields. Riis brings in an institutional perspective from Norway focusing on the research field of design didactics. From 1976, teacher education institutions in Oslo and Notodden, Norway, have offered MA-level education which includes the students' practical-aesthetic work (Fauske, 2014). This has grown a tradition and basis for conducting research in the interplay between creative practice, teaching and research in all three educational cycles. In the period from 1995-2010 students from the field of design didactics in Norway were included in the doctoral programme at AHO, which contributed to develop a broader platform for this kind of research characterized by "doctorateness", "scholarship" and "critical mass" (Dunin-Woyseth \& Nilsson 2012, Nielsen 2018) for the research field of both architecture, design and design didactic, stated as the "making disciplines" by Dunin-Woyseth and Mitchl (2001). Most research in the field of design didactics is conducted as research on craft practice. In the research projects mentioned above, the researcher is both practitioner and teacher but except from Riis (2016), the research explores other practitioners and does not explore the practice from an inside perspective. Riis conducted research through creative practice, though primarily intended to inform the research. Thus, the creative output from Riis' research was not acknowledged as a research result. Following Riis \& Groth (2020, p. 4-5), research including 
output from creative practice as research results can be linked to the concepts practice-based research and artistic research, and research including creative practice not as research results but to inform the research - can be linked to the concepts of practice-led research, (see also Candy \& Edmund, 2018).

\section{DISCUSSION}

This paper explores how different educational perspectives can interweave new synergies to be beneficial and fruitful to the research of craft practice and knowledge production for craft learning communities. We identified an opportunity to spin theoretical threads for the grounds of our research project and institutional traditions. The lines overlap and refer both to the history of research within creative practice and institutional traditions and ambitions. Here, we identify paradoxes between academicization of the design profession and the explorative research design presented above, with strong emphasis on experimentation and to explore craft practice and learning as its distinct character as living, embodied and transformative.

We are intrigued by this paradox, which leads us to discuss questions related to both the neutral learning arena and methodological issues about the researchers' roles. Related to the neutral learning arena setting, questions raised are for example; What are the implications of suggesting a neutral learning arena set up for students and employees in a traditional education system? How do the educational cultures within Denmark and Norway differ and how can that affect the research project? How should the neutral learning arena be organized and settled to be able to "reset" the participants' contextual preconceptions of craft, making and learning?

Questions implied the research methodology are for example; what will the challenges be of organizing the set-up, with the roles as both makers, participants and researchers? How will each of us, in this complex position, be able to handle the challenges and opportunities throughout the project? Participating observations might be referred to as observa(c)tions, legitimizing and emphasizing the acting, participating researcher, and the CCMs outlined as experiments. This deliberately includes the premise that we cannot predict the outcome of these interrelations, yet, it seems to be a multifaceted premise of participating and doing research in a neutral learning arena.

In relation to the other involved participants in the project who will benefit from the experience of studying or teaching, we need to explore how the outcomes of the CMMs are evaluated. Among others, figure 3 puts out more questions for the research collaboration to deal with before, under and after the project. Questions discussed to gain new insights on learning communities is for example; how is the relationship between the learner and master? What characterizes this type of learning? How to maintain and grow respect for different competencies? How to encourage the participants to share, learn, challenge and share competencies and experiences in the learning community, including "risks and gains"? How is learning facilitated and identified? Do the masters participate in, contribute to or develop the learning community? And lastly, it is noteworthy to discuss and reflect how we as researchers (from each of our institutional traditions) participate and possibly affect the learning community as being both active craft practitioners and researchers of the actions involved.

Finally, while learning in a neutral learning arena - the scope of the research project is affected by our common interest and perspective on sustainability as an overarching goal for all craft practice, production and learning. This dimension constitutes a premise for this particular research project, which will be needed clarified and utilized in phase 1 of the project. The element of sustainability and research focus can be seen as a transformative research inquiry; an overarching ambition for the research project in the organizing, facilitation, practicing, handling of materials, communication as well as the activities related to the project. 


\section{Concluding remarks}

During this paper, we have started the first phase of the project and an initial 'spinning' process utilizing theoretical threads from the two researchers' contexts. Before the conference we intend to refine the theoretical thread/s to be applied in our further "weaving" process. Due to the coronasituation, we plan to establish a three-day CRAFT/MAKING/MEETING pilot, limited number of participants (2 researchers, 2-3 older generation volunteers, freelance designers and arts and craft persons) situated at a neutral learning arena. We plan to execute the CMM pilot in February 2021, and hope to be able to present the outcome and new insights at the BICCS in May 2021. At the conference presentation, we hope to have feedback and discussions that will improve the research project and prepare CMM1. 


\section{REFERENCES}

Alvesson, M., \& Sköldberg, K. (2008). Tolkning och reflektion Vetenskapsfilosofi och kvalitativ metod (2. ed.). Studentlitteratur.

Archer, B. (1995) The Nature of Research. CoDesign (January), 6-13.

Bang, A. L. and Agger Eriksen, M. (2014) Experiments all the way in Programmatic Design Research. Artifact, 3(2),2.1-2.x. https://doi.org/10.14434/artifact.v3i2.3976

Bang, A.L. (2011. Emotional Value of Applied Textiles: Dialogue-oriented and Participatory Approach to Textile Design. [PhD thesis. Design School Kolding/Gabriel, Kolding, Denmark].

Barone, T \& Eisner, E. W. (2011). Arts Based Research. SAGE Publications.

Bayazit, N. (2004). Investigating Design: A review of Forty Years of Design Research. Design Issues, 20(1), 16-29. https://doi.org/10.1162/074793604772933739

Binder, T. \& Brandt, E. (2008). The Design:Lab as platform in participatory design research. CoDesign 4(2): 115129. https://doi.org/10.1080/15710880802117113

Binder, T. \& Redström, J. (2006) Exemplary Design Research. In K. Friedman, T. Love \& E. Corte-Real (Eds.) Proceedings of Design Research Society Wonderground International Conference 2006.

Bloomberg, J., Gicomi, J., Mosher, A., and Swenton-Wall, P. (1993). Ethnographic field methods and their relation to design. In D. Schuler \& A. Namioka (Eds), Participatory Design: Principles and Practices. Lawrence Erlbaum Associates.

Brandt, E. \& Binder, T. (2007). Experimental Design Research: Genealogy - Intervention - Argument. IASDR 2007 Proceedings. Emerging Trends in Design Research. Hong Kong, 12-15 November 2007.

Brinkmann, S. (2014). Doing without Data. Qualitative Inquiry, 20(6), 720-725. https://doi.org/10.1177/1077800414530254

Candy, L. \& Edmonds, E. (2018). Practice-based research in the creative arts, foundations and futures from the frontline. Leonardo, 51(1), 63-69. https://doi.org/10.1162/LEON_a_01471

Designskolen Kolding. (2018). Knowledge Production Strategy. https://www.designskolenkolding.dk/sites/default/files/download/videnstrategi_61.pdf

Dunin-Woyseth, H,. \& Michl, J. (2001). Towards a disciplinary identity of the making professions: An introduction. In H. Dunin-Woyseth \& J. Michl (Eds.), Towards a disciplinary identity of the making professions. (Vol. 4, pp. 1-20). Oslo School of Architecture.

Dunin-Woyseth, H., \& Nilsson, F. (2012). Doctorateness in design disciplines. FORMakademisk, 5(2), 1-11. https://doi.org/10.7577/formakademisk.499

Ellis, C. and Bochner, A. (2000). Autoethnography, Personal Narrative, Reflexivity: Researcher as Subject. In N. K. Denzin \& Y. S. Lincoln (Eds.), Handbook of Qualitative Research (2nd Ed.) (pp. 733-768). SAGE Publications.

Frayling, C. 1993. Research in art and design. Royal College of Art Research Papers, 1(1), 1-5.

Fredriksen, B.C. (2011). Negotiating grasp: Embodied experience with three-dimensional materials and the negotiation of meaning in early childhood education. [Doctoral theses, Oslo School of Architecture and Design]. http://hdl.handle.net/11250/93056

Groth, C. (2016). Design and craft thinking analysed as embodied cognition. FormAkademisk, 9(1), 1-21. http://dx.doi.org/10.7577/formakademisk.1481

Gulliksen, M. S. (2017). Making matters? Unpacking the role of practical aesthetic making activities in the general education through the theoretical lens of embodied learning. Cogent Education, 4(1), 1415108.doi:10.1080/2331186X.2017.1415108

Irwin, Springgay \& Kind. (2005). A/r/tography as Living Inquiry Through Art and Text. Qualitative Inquiry, 11(6), 897-912. https://DOI:10.1177/1077800405280696

Kirketerp, A. (2020) Craft Psykologi. Mailand. 
Krogh, P.G., Markussen, T. and Bang, A.L. (2015). Ways of drifting - 5 methods of experimentation in research through design. In Proceedings of ICoRD: International Conference on Research into Design. Indian Institute of Science, Bangalore, India; January 7-9.

Kvale, S., Brinkmann, S., Anderssen, T., \& Rygge, J. (2015). Det kvalitative forskningsintervju (3. ed.). Gyldendal akademisk.

Lave, J., \& Wenger, E. (2003). Situeret læring - og andre tekster. Reitzel.

Markussen, T., Bang, A. L., Knutz, E., \& Pedersen, P. (2012). Dynamic Research Sketching: A new explanatory tool for understanding theory construction in design research. In Proceedings of the 8th International Design Research Society Conference.

Molander, B. (2015). The Practice of Knowing and Knowing in Practices. Peter Lang. https://doi.org/10.3726/978-3-653-06131-4

Møller, T \& Kettley, S. (2017) Wearable health technology design: A humanist accessory approach. International Journal of Design, 11(3), 35-49. http://www.ijdesign.org/index.php/IJDesign/article/view/2842/792

Møller, T. (2019a) Wearing Health Products - A wearer-led accessory approach to wearable health design. [PhD thesis. Design School Kolding, Denmark].

Møller, T. (2019b). Access through Accessories. Journal of Jewellery Research, 2(February).

Niedderer, K. (2013). Explorative materiality and knowledge: The role of creative exploration and artefacts in design research. FormAkademisk, 6(2), 1-20. https://doi.org/10.7577/formakademisk.651

Nielsen, L. M. (2018). Building making scholarship. FormAkademisk, 11(1). https://doi.org/10.7577/formakademisk.3099

Riis, K. (2016). Designkundskabens DNA: Udforskning af designkunskab gennem designprocessen Mit DNA. [The DNA of design knowledge: Exploration of design knowledge through the design process My DNA.][Doctoral dissertation, Det humanistiske fakultet, Institutt for filosofi og religionsvitenskap of [Doctoral dissertation, The Norwegian University of Science and Technology NTNU]. https://brage.bibsys.no/xmlui/handle/11250/2393093

Scheider, B. (2007) Design as Practice, Science and Research. In Mitchel, R. (Ed), Design Research Now (pp. 8189). Board of International Research in Design.

Sennett, R. (2008). The Craftsman. Penguin books.

Yin, R. K. (2003). Case study research: Design and methods. SAGE Publications. 